\title{
The International Policy Trilemma in the Post-Bretton Woods Era
}

\author{
Alex S. Mandilaras* \\ University of Surrey
}

February 13, 2015

\begin{abstract}
The international macroeconomic policy trilemma suggests that despite the appeal of exchange rate stability, financial account openness and monetary sovereignty, these cannot be achieved simultaneously. Using elements of Euclidean geometry, this paper proposes a new method for testing the trilemma and finds considerable evidence in support of it. Further tests indicate that, on average, policy configurations are not on the trilemma constraint, i.e. there is a degree of 'trilemmaineffectiveness', which is costly for real output growth and price inflation. It is shown that these costs can be attributed to limited exchange rate stability and financial account openness.
\end{abstract}

Keywords: International Policy Trilemma, Exchange Rate Stability, Financial Openness, Monetary Sovereignty

JEL: F33

*Email: a.mandilaras@surrey.ac.uk. Address: School of Economics, University of Surrey, GU2 7XH, Surrey, UK. Tel.: +44 (0)1483 682768. I thank Helen Popper for insightful discussions over the years. Also, Michael Bleaney, Paul Levine, Ioannis Lazopoulos and, especially, Graham Bird for useful comments on an earlier draft. All errors are mine. 


\section{Introduction}

There are several reasons why each aspect of the international macroeconomic trilemma - exchange rate stability, financial account openness and monetary sovereignty - may appeal to policymakers. Exchange rate stability prevents unnecessary resource shifts into and out of trade-oriented sectors that may result from exchange rate overshooting; it may be desirable as a nominal anchor for inflationary expectations; and, it protects a dollarised banking system from balance sheet shocks. ${ }^{1}$ Financial openness should lead to an increase of investment inflows, which boosts output in the short-run. ${ }^{2}$ It may also generate long-run benefits through a more efficient allocation of capital and by increasing the costs of policy mistakes and lack of reforms. ${ }^{3}$ Monetary sovereignty allows for a more effective policy toolbox both for achieving internal balance and for responding to external shocks.

But, despite the attractiveness of each aspect of the trilemma, a policymaker cannot achieve all three simultaneously. For example, operating an open financial account and achieving perfect exchange rate stability necessarily implies the loss of monetary sovereignty. Any effort to change the monetary base (or, correspondingly, the interest rate) will lead to offsetting actions by the central bank in order to maintain the current level of the exchange rate. In the case of an expansion accompanied by a lower interest rate, the reduction in capital inflows will tend to weaken the domestic currency. In order to prevent the exchange rate (expressed here as the price of the foreign currency in local currency units) from appreciating, the central bank will have to absorb

\footnotetext{
${ }^{1}$ See Calvo and Reinhart (2002).

${ }^{2}$ See Bussière and Fratzscher (2008).

${ }^{3}$ The seminal contribution of Kose et al. (2009) explores all aspects of financial globalisation and concludes that it can have a "catalytic role" for total factor productivity (TFP) growth and welfare in developing countries.
} 
the extra liquidity it has generated by running down its international reserves. So, in order to maintain a degree of monetary sovereignty, the country needs to implement restrictions in its financial account or sacrifice - to the required extent - the exchange rate stability objective. ${ }^{4}$

This logic presumes that there are limits to the extent that the monetary authority can sterilise the foreign exchange market intervention by injecting liquidity in the banks' balance sheets. Sustaining a monetary expansion under fixed exchange rates with an open financial account would require a prolonged reserve haemorrhage, something which the policymaker cannot accept for too long. ${ }^{5}$ Irrespective of the hoard, international reserves are an exhaustible resource and such policies cannot persist indefinitely. Ultimately, the trilemma should be a binding constraint.

In spite of the importance of the trilemma's implications for conducting macroeconomic policy, systematic efforts in assessing its empirical validity using large datasets are relatively recent. ${ }^{6}$ This paper contributes to the related literature by offering a new way of testing the trilemma using elements of Euclidean geometry. The procedure is described, and, using data from the post-Bretton Woods era, implemented in section 2. In addition, the paper explores the macroeconomic consequences of failing to implement policies that maximise the extent to which the three aspects of the trilemma are met. This is done in section 4, following the introduction of the term 'trilemma effectiveness' in section 3. Section 5 concludes.

\footnotetext{
${ }^{4}$ See Aizenman (2013) for more examples on the constraint the trilemma places on policymakers.

${ }^{5}$ Quantitatively, the relationship between the change in the domestic component of the monetary base and the corresponding change in international reserves is captured by the offset coefficient. An early discussion of sterilisation and the offset coefficient can be found in Herring and Marston (1977).

${ }^{6}$ See, e.g., Shambaugh (2004), Obstfeld et al. (2005), Bleaney et al. (2013) and Aizenman et al. (2013).
} 


\section{The Trilemma Constraint}

Previous studies have investigated the trilemma constraint by gauging the responsiveness of the domestic interest rate to the foreign one (the latter is the interest rate of an appropriately selected 'base' country). The interest rate of a country implementing a fixed exchange rate regime with an open financial account will converge to - and fluctuate in tandem with - the foreign interest rate. If this is not the case, then there will be arbitrage opportunities. For example, a too-high domestic interest rate vis-à-vis the foreign interest rate will see an inflow of foreign capital exploiting the differential. This inflow, given perfect capital mobility, will result in higher asset prices and lower yields. The arbitrage activity will continue until the interest rate differential between the domestic and foreign assets, which are assumed to be perfect substitutes, is zero. $^{7}$

In other words, under these arrangements, a country is not expected to possess a meaningful degree of control over its monetary policy. Shambaugh (2004) and Obstfeld et al. (2005) find evidence that broadly support this expectation. Bleaney et al. (2013) find that pegs without capital controls are linked to a higher degree of monetary sovereignty than the constraints of the trilemma would suggest. Nevertheless, when they account for peg credibility issues, their results become more consistent with the trilemma. ${ }^{8}$

A different approach, more closely related to the one pursued in this paper, is implemented by Aizenman et al. (2013). Instead of concentrating on interest rate correlations, they include measures of exchange rate stability, financial

\footnotetext{
${ }^{7}$ In reality, however, transaction costs may allow a financially open, exchange rate-fixing country some degree of monetary sovereignty. This is a point made by Obstfeld et al. (2005).

${ }^{8}$ Their argument is that in low-credibility pegs, devaluation expectations feed into the domestic interest rate disentangling it to some extent from the base country's rate and generating a false perception of relative monetary independence.
} 
account openness and monetary sovereignty in a regression framework. Their three goals are to determine whether the relationship among the three trilemma variables is a linear one, to obtain estimates of the tradeoffs between them and to test the trilemma itself. They find that the trilemma has been binding for industrialised countries since the early 1990s and for developing countries since the mid 2000s. Most important for the aims of this paper, their results suggest that the relationship between the trilemma variables is likely to be a linear one.

The presumption of linearity allows the depiction of the trilemma constraint as a triangle in the space defined by the three aspects of the trilemma. This is shown in Figure 1 as triangle $A B C$. At each point in time, the combination of exchange rate stability, financial account openness and monetary sovereignty determines each country's location in this three-dimensional space. In the context of this paper, each point represents a macroeconomic policy outcome (or configuration). If the trilemma is binding, then the mean distance between the constraint and policy configurations exceeding the constraint, i.e. points that lie off the trilemma triangle in the opposite direction of the origin, will be statistically insignificant. This is the essence of the test proposed and implemented in this paper.

\section{[INSERT FIGURE 1 ABOUT HERE]}

The trilemma constraint is given by

$$
s+m+f-2=0,
$$

where $s$ stands for exchange rate stability (the abscissa in Figure 1), $m$ stands for monetary sovereignty (the ordinate) and $f$ stands for financial account 
openness (the height), and $0 \leq s, m, f \leq 1$. Geometrically, the distance between a point and a plane is found by projecting a vector that connects the point of interest with a point on the plane onto the unit normal vector (i.e. a vector of length one, which is perpendicular to the plane). The length of a vector $\mathbf{v}$ connecting, e.g., a point $P\left(s_{1}, m_{1}, f_{1}\right)$, which is off the plane, and, e.g., a point $Q(s, m, f)$, which lies on the plane, is

$$
\mathbf{v}=\left|\begin{array}{c}
s_{1}-s \\
m_{1}-m \\
f_{1}-f
\end{array}\right| .
$$

Given (1), the unit normal vector $\mathbf{u}$ is ${ }^{9}$

$$
\mathbf{u}=\frac{(1,1,1)}{\sqrt{3}}
$$

The projection is just $|\mathbf{v} \cdot \mathbf{u}|$. Hence, the distance, $k$, is

$$
k=\frac{\left|\left(s_{1}-s\right)+\left(m_{1}-m\right)+\left(f_{1}-f\right)\right|}{\sqrt{3}} .
$$

Substituting the trilemma constraint in (4) yields

$$
k=\frac{\left|s_{1}+m_{1}+f_{1}-2\right|}{\sqrt{3}} .
$$

Dropping the absolute value gives the 'signed' trilemma distance (henceforth, trilemma distance): a negative value means that the point in question lies somewhere between the origin and the trilemma plane, whereas a positive value means that the point lies off the plane in the opposite direction of the

\footnotetext{
${ }^{9}$ More generally, it is $\frac{a, b, c}{\sqrt{a^{2}+b^{2}+c^{2}}}$ for a plane described by an equation $a x+b y+c z=d$.
} 
origin. ${ }^{10}$

In order to calculate the distance between a configuration and the trilemma triangle, I use an updated version of the dataset from Aizenman et al. (2010). This features annual data on exchange rate stability, financial account openness and monetary sovereignty. The measure of the degree of exchange rate stability, $s$, is constructed using monthly observations of the exchange rate, $e$, vis-á-vis a base currency (most frequently but not always the US dollar). For country $j$ in a given year, it is

$$
s_{j}=0.01 \times\left[0.01+\sqrt{\sum_{t=1}^{n_{j}} \frac{\left(\Delta \log \left(e_{j t}\right)-\overline{\Delta \log \left(e_{j}\right)}\right)^{2}}{n_{j}-1}}\right]^{-1}
$$

with $n_{j}$ being the number of available monthly observations for country $j$ in that year. The measure of the degree of monetary independence, $m$, is constructed using monthly observations of money market interest rates. For country $j$ in a given year, it is

$$
m_{j}=0.5 \times\left[1-\frac{\sum_{t=1}^{n_{j}}\left(i_{j t}-\overline{i_{j}}\right)\left(i_{k t}-\overline{i_{k}}\right)}{\sqrt{\sum_{t=1}^{n_{j}}\left(i_{j t}-\overline{i_{j}}\right)^{2} \sum_{t=1}^{n_{j}}\left(i_{k t}-\overline{i_{k}}\right)^{2}}}\right]
$$

with $i_{j}$ being the interest rate of 'home' country $j$ and $i_{k}$ being the interest rate of the 'base' country $k .^{11}$ The IMF's Annual Report of Exchange Arrangements and Exchange Restrictions is used to construct a de jure measure of capital account openness. This is calculated as the first principal component of variables representing controls on the current and capital accounts, the

\footnotetext{
${ }^{10}$ There is, of course, no concept of negative distance: the sign solely identifies the direction.

11 Aizenman et al. (2010) make certain adjustments to these measures in order to deal with the tendency of $s$ to overstate flexibility and of $m$ to be 'noisy'. For more information see the notes on their paper available at http://web.pdx.edu/ ito/trilemma_indexes.htm.
} 
presence of multiple exchange rates and the treatment of export proceeds. ${ }^{12}$ Similarly to $s$ and $m$, it is normalised to take values between zero and one.

The dataset consists of 5,289 usable observations - i.e. years between the period 1970 and 2012 for which the distance from the plane can be calculated. Table 1 reports overwhelming evidence that policy configurations are, on average, consistent with there being a binding trilemma constraint. This is true across income groups (panel A in Table 1), geographic regions (panel B) and time (panel $\mathrm{C}$ ), as evidenced by the negative average values for the trilemma distance variable.

\section{[INSERT TABLE 11 ABOUT HERE]}

A more formal test of the trilemma involves testing the null hypothesis that the mean of the trilemma distance is zero against the alternative that it is positive. Inability to reject the null is interpreted as evidence that the constraint is binding, i.e. that the mean of the positive values observed are insignificant. ${ }^{13}$

A natural candidate for this assessment is a Student's t-test. The latter is based on the classical assumptions about the distribution of observations, including the assumption of normality. Statistically, this is rejected for the trilemma distance variable. ${ }^{14}$ However, the extent of similarity between the normal density and the variable's kernel density - both plotted along with a histogram in Figure 2 is conducive to using the t-test. Results are reported in

\footnotetext{
${ }^{12}$ For more details see Chinn and Ito (2006).

${ }^{13}$ Why these exist in the first place is an important question, but not one that is pursued here. One explanation could be that the degree of monetary sovereignty is actually exaggerated as it may reflect credibility issues rather than actual monetary independence. See Bleaney et al. (2013) for details.

${ }^{14}$ Skewness is equal to 0.12 and the hypothesis that the difference with the degree of skewness of a normal distribution is zero cannot be rejected. Hence, on this criterion, normality cannot be rejected. However, one should reject the same hypothesis about kurtosis (equal to 2.5).
} 
the last column of Table 1 for the entire sample, income groups, geographical regions and decades in the sample. In all cases, the null cannot be rejected. ${ }^{15}$

[INSERT FIGURE 2 ABOUT HERE]

\section{Introducing Trilemma Effectiveness}

The numbers reported in Table 1 show that, on average, trilemma distance is negative. In this paper, this situation is defined as 'trilemma ineffectiveness'. In contrast, an observation corresponds to a trilemma-effective configuration if the mean lies on the trilemma plane, i.e. if $k=0$, or exceeds it. Statistical tests (not reported here but available from the author upon request) reject the hypothesis that the average trilemma distance is zero, in favour of the alternative that it is negative. The aim of this section is to probe the extent of trilemma ineffectiveness. ${ }^{16}$

The numbers reported in Panel A of Table 1 show that low-income countries are, collectively, the most trilemma-ineffective. In other words, these countries could enjoy the benefits of a greater degree of financial account openness, exchange rate stability or monetary independence - or a combination of these-by implementing the relevant policies. Middle-income countries are more trilemma-effective, even though they are some way off the, historically, better performing high-income group.

\footnotetext{
${ }^{15}$ Table $\mathrm{A} 1$ in the Appendix reports results for individual countries. Again, the null cannot be rejected in the majority of cases.

${ }^{16}$ Explaining why observed policies are not closer to the trilemma constraint, i.e. identifying the reasons behind trilemma ineffectiveness, would be a natural extension of this work. One possible line of research would be to consider whether varying trilemma distances reflect varying levels of capital mobility. The latter may not necessarily coincide with the extent of financial openness because of, e.g., changes in investors' degree of risk-aversion. That could lead to a reduction of cross-country asset substitutability and, consequently, of capital mobility. This argument is offered by Globan (2014) who uses trilemma deviations as a measure of capital mobility for 11 European post-transition economies.
} 
But what are the precise policy profiles of the three income groups? The top graphic in Figure 3 clarifies this. High-income countries are the most financially open while enjoying a similar degree of exchange rate stability with the other groups. Naturally, they have the least independent monetary policies, even though not to an extent that would jeopardise their relative trilemma effectiveness. In contrast, low-income countries, have a low degree of financial account openness and, at the same time, the lowest degree of exchange rate stability. This, consequently, affords them a more independent monetary policy compared to the other income groups, especially the high-income group. Still, the average degree of monetary sovereignty is far from perfect, and, consequently, their monetary policies are not truly shielded from the world's monetary conditions.

\section{[INSERT FIGURE 3 ABOUT HERE]}

A breakdown of average trilemma effectiveness by geographical region for low and middle-income countries reveals that economies in the Latin America and Caribbean region have implemented trilemma policies that are as effective as those of high-income countries. This region, as a whole, is also substantially more financially open than the rest, even though it is not as open as highincome countries. Europe and Central Asia, South Asia, Sub-Saharan Africa and East Asia and the Pacific are at the other end of the spectrum, where large improvements in trilemma effectiveness could be made. Middle East and North Africa's average policy configuration is closer to the trilemma constraint. Overall, the economies in our sample took big steps towards trilemma effectiveness in the 1990s and 2000s. This period corresponds to the opening up of financial accounts, as can be seen in the bottom graphic of Figure 3 . 


\section{Trilemma Effectiveness and Macroeconomic Performance}

\subsection{Initial considerations}

Having established that international macroeconomic policy is broadly bound by the trilemma, it is natural to ask whether trilemma effectiveness is linked to macroeconomic performance. Two aspects of the latter are examined, real economic growth and price inflation outcomes. The a priori expectation regarding growth is that economies achieving a greater degree of exchange rate stability, financial openness and monetary autonomy should grow faster - even though there are some qualifications to this assertion. Calvo and Reinhart (2002) report a "widespread" aversion to large currency swings, especially among emerging economies. They offer a range of possible explanations for this aversion, including the existence of output costs associated with exchange rate fluctuations. Aghion et al. (2009) find that real exchange rate volatility can indeed have a significant impact on productivity growth, especially in less financially developed economies.

The role of financial integration has been explored in a number of studies, many of which have established a positive correlation with economic growth. As mentioned in the introduction, Kose et al. (2009) conclude that the effects on TFP growth can be catalytic for developing countries. Using data for the period 1976-1995, Klein and Olivei (2008) find that countries with more open capital accounts grow faster, even though this result is driven by the developed countries in their sample. But, of course, an open financial account does not guarantee a smooth inflow of investment from abroad. Calvo (1998) shows how capital may suddenly stop flowing into the domestic economy with 
deleterious effects. And, more recently, Rey (2013) has argued that the extent of financial integration in recent times has led to a 'global financial cycle'. As this tends to be unrelated to individual economies' macroeconomic conditions, it generates credit booms and busts. The implication is that irrespective of the exchange rate regime, an open capital account is equivalent to a loss of monetary independence. And this can lead to crises, if, for example, the global financial cycle leads to an 'extreme' credit expansion.

The link between trilemma effectiveness and inflation is more difficult to infer from the theory because in the small open economy framework of MundellFleming prices are sticky. Real world considerations, however, give rise to an expectation that, on balance, the two should move in opposite directions. The first consideration is exchange rate stability. In the long run, if purchasing power parity holds, a stable exchange rate can be seen as an indication of a credible anti-inflation monetary stance. Hence, it should be linked to lower inflation rates. ${ }^{17}$ The second consideration is financial integration. The potential link between an open financial account and prices is a priori quite uncertain. If unemployment is low and the financial account leads to a higher inflow of direct investment, there could be upward pressure on wages and prices. Or, in different circumstances, the additional domestic production due to capital inflows could put downward pressure on product prices. Increased inward investment may also increase the value of the domestic currency making imports cheaper, and, hence, help reduce inflation. Available empirical evidence are consistent with the argument that financial integration should be linked to lower inflation rates, e.g. Wei and Tytell (2004). Finally, monetary indepen-

\footnotetext{
${ }^{17}$ Note that exchange rate stability is not necessarily a feature associated only with exchange rate pegs. It could be the case that the currency is stable within a flexible exchange rate framework. It is also possible that instability is associated with a fixed exchange rate regime if the latter is readjusted frequently or abandoned altogether.
} 
dence can cut both ways. It should be good news for inflation outcomes if the monetary authorities have established their anti-inflation credentials. Equally, it should be bad news if the monetary authorities lack such credibility. Ultimately, the precise relationship between trilemma effectiveness and inflation is an empirical question, which is what this paper tries to answer next.

This very brief discussion has touched upon the issues surrounding international macroeconomic policy, the latter being defined as the combination of exchange rate stability, financial account openness and monetary independence. Depending on preferences, a policymaker may want to pursue one particular policy at the expense of another, but, overall, and in the long-run, they will want to adopt a configuration that places the economy on the trilemma constraint. For example, if a policymaker values exchange rate stability but would like to manage the financial account, then she would expect to get at least some degree of monetary sovereignty.

\subsection{Data and methodology}

The degree of trilemma effectiveness is captured by the trilemma distance variable. ${ }^{18}$ Recall that it is a 'signed' distance in that a negative value shows that the trilemma constraint has not been violated and a positive sign shows that it has. ${ }^{19}$ Values corresponding to points closer to the constraint, on it, or exceeding it are preferred to points that lie away from the constraint and towards the origin, as they correspond to more favourable combinations of the three aspects of the trilemma.

The functional forms of the estimated growth and inflation equations are

\footnotetext{
${ }^{18}$ The configuration is observed but is not 'actual' due to the de jure nature of financial account openness. This point is discussed further in the conclusions.

${ }^{19}$ The analysis in the previous section has shown that, collectively, the hypothesis of a positive mean trilemma distance is rejected.
} 
similar to Husain et al. (2005), augmented with the trilemma effectiveness measure. Descriptive statistics for all variables are presented in Table 2, The dependent variable in the growth equation is the natural log change per annum of GDP per capita in 2005 international dollars (using PPP rates). ${ }^{20}$ In explaining growth, factor accumulation is captured via the inclusion of investment (gross fixed capital formation divided by GDP) and population-both in level (natural log) and as a growth rate (change in natural log). ${ }^{21}$ The government sector is captured by the budget balance (as a share of GDP) and tax revenue (again as a share of GDP). In addition, imports plus exports (percent of GDP) and terms of trade (change in the natural log of net barter terms of trade) are also included. ${ }^{22}$

\section{[INSERT TABLE 2 ABOUT HERE]}

The inflation equation features M2 growth, real output growth (as defined above), imports plus exports as a share of GDP, terms of trade growth, the budget balance as a share of GDP and the central bank governor's time in office. ${ }^{23}$

The econometric specifications feature country fixed effects or country and time fixed effects (year dummies). Inclusion of country effects controls for individual country characteristics that are not captured by the explanatory variables (e.g. the quality of institutions). The year dummies capture exter-

\footnotetext{
${ }^{20}$ The source for all variables is the World Bank's World Development Indicators, unless otherwise stated.

${ }^{21}$ Data for the mean years of schooling for over-25s (source: UNESCO) were collected in order to capture the effect of human capital on economic growth. However, the number of observations is too small to include this variable in the specification.

${ }^{22}$ To capture output convergence, each country's real output per capita was divided by US's real output per capita in 1980 (the first year for which US data are available for this variable). It turns out that the estimated coefficient of this variable is insignificant in all estimations and does not affect the estimates of trilemma distance. Hence, it is not included in the model.

${ }^{23}$ Data for the latter are from Dreher et al. (2010).
} 
nal shocks that affect all countries (e.g. a US monetary policy shock). The resulting specification, where both country and time dummies are included, captures the relationship between trilemma effectiveness and macroeconomic performance within countries.

The decision to model effects as fixed rather than treat them as random was based on the results from a test by Schaffer and Stillman (2006). This test is appropriate for use in panel data estimations where standard errors are cluster-robust, i.e. errors that are robust to cross-sectional heteroscedasticity and within-panel serial correlation. ${ }^{24,25}$ The Wald test statistic leads to the rejection of random effects in both the estimated inflation and growth equations.

Finally, a lag of the dependent variable is introduced in the list of explanatory variables in order to control for persistence effects. Strict exogeneity is assumed, i.e. a shock in the error term is not supposed to exert influence on current or future values of any of the independent variables. Clearly, this is a restrictive assumption, but one that is relaxed in robustness checks. The two-step system estimator of Blundell and Bond (2000) is used with correction for hetroscedasticity in the errors.

A question arises as to how to treat the positive values of the distance variable $k$, as they could, potentially, represent measurement bias. One possibility is that a de jure open financial account may not coincide with de facto perfect capital mobility if domestic and foreign investment assets are imperfect substitutes. In such cases, the degree of capital mobility will be overstated and the monetary authorities may have greater monetary leeway than predicted by the trilemma. Positive values of $k$ would then result from incorrectly measuring

\footnotetext{
${ }^{24}$ The commonly used Hausman test is not suitable in this case. The two tests are asymptotically equivalent under conditional homoscedasticity.

${ }^{25}$ For more details on cluster-robust errors see Nichols and Schaffer (2007).
} 
the elasticity of international capital flows with respect to changes in domestic interest rates.

A different measurement bias, however, pushes in the opposite direction. The measure of monetary independence used here may be understating the true extent of the ability of central banks to conduct monetary policy. A high correlation between country interest rates may be indicative of a common shock rather than monetary dependence per se. ${ }^{26}$ With exchange rate stability captured reasonably accurately, attributing $k$ 's positive values to a measurement bias presupposes that the effect of overstating capital mobility exceeds that of understating monetary independence.

An alternative explanation could be that, in the short run, the trilemma constraint is not binding for countries with a sufficient stock of international reserves. ${ }^{27}$ For example, a monetary expansion under perfect capital mobility and fixed exchange rates may be effective if the central bank increases its holding of net domestic assets at the expense of net foreign assets, which results from sterilising the foreign exchange market intervention that is necessary to stabilise the exchange rate. Even in the absence of a measurement bias, this would correspond to positive values of $k$.

The two explanations have different ramifications for the distance variable. If the positive values are down to a measurement bias, then they need to be replaced by zeros. In contrast, there is no such requirement if one accepts the international reserves explanation to be true. In practice, however, whether variable $k$ is truncated or not makes little difference and the results are almost identical. The results reported here feature the non-truncated data.

\footnotetext{
${ }^{26}$ See Popper et al. (2013) for a criticism of the interest rate correlation approach to measuring monetary independence.

${ }^{27}$ See Steiner (2013) for an empirical assessment of the extent to which international reserves are built up as a substitute for capital controls.
} 


\subsection{Main Results}

Table 3 reports results for the growth equation. The baseline model, where trilemma effectiveness is the only explanatory variable of growth, shows that the link between the two variables is statistically significant. This result does not depend on whether year dummies are added to the specification. It also survives almost intact the inclusion of variables from Husain et al. (2005) in the augmented specification. In the latter, investment, population growth and the budget balance are statistically significant and with the expected sign under both effects formulations (country-only and time and country effects). The dynamic specification results confirm the importance of trilemma-effective policies. $^{28}$

\section{[INSERT TABLE 3 ABOUT HERE]}

Table 4 reports results for the inflation equation. The estimates of trilemma effectiveness in the baseline equations are, as expected, negative and statistically significant. Even as part of a richer specification (the augmented models) this remains the case and, along with money growth and real output growth, trilemma effectiveness is a significant determinant of inflation in the sample. The dynamic specification results are slightly more ambiguous, as the inclusion of year dummies removes the significance from the trilemma effectiveness coefficient. But, the overall picture that emerges from these models is difficult to blur: trilemma ineffectiveness goes hand-in-hand with higher inflation rates. $^{29}$

\section{[INSERT FIGURE 4 ABOUT HERE]}

\footnotetext{
${ }^{28}$ The estimations were repeated sequentially treating investment as a predetermined or endogenous variable. The thrust of the results remained unaffected.

${ }^{29}$ Allowing money growth to be predetermined or endogenous does not change the results materially.
} 


\subsection{Additional Results: Breaking down the trilemma}

These results warrant further exploration. If trilemma ineffectiveness is associated with macroeconomic costs, is it possible to identify the precise aspect of the trilemma that underlies this link? In order to answer this question, the relative importance of the distance between policy configurations and the trilemma triangle's vertices $(A, B$ and $C$ in Figure 1 needs to be quantified. More specifically, each vertex corresponds to a combination of the maximum possible value for two of the trilemma policy objectives and zero for the other. Point $A$ depicts a financially open economy with stable exchange rates ("Stable, Open"); point $B$ depicts a financially open economy with monetary sovereignty ("Open, Sovereign"); and, point $C$ depicts a financially closed economy with monetary sovereignty ("Stable, Sovereign"). The distance from each vertex is calculated using the Euclidean norm:

$$
d_{i t, x}=\sqrt{\left(s_{i t}-\tilde{s}\right)^{2}+\left(m_{i t}-\tilde{m}\right)^{2}+\left(f_{i t}-\tilde{f}\right)^{2}}
$$

where $x=(A, B, C)$ and $(\tilde{s}, \tilde{m}, \tilde{f})$ is $(1,0,1)$ for vertex $A,(0,1,1)$ for vertex $B$, and $(1,1,0)$ for vertex $C$; subscript it indexes a country $i$ and year $t$ observation; $s, m$ and $f$ stand for exchange rate stability, monetary sovereignty and financial account openness, as before.

The results under Specification I column of Table 5 are from the growth and inflation models where trilemma effectiveness has been replaced by the distances from the stable and open, open and sovereign, and stable and sovereign configurations. For the growth equation, the greater the distance from points $A$ (stable and open) and $C$ (stable and sovereign), the lower the real growth rate. The distance from point $B$ (open and sovereign) is not significant. Since the common element of points $A$ and $C$ is exchange rate stability, it is likely 
that this aspect of trilemma policies is associated with higher economic growth.

\section{[INSERT TABLE 5 ABOUT HERE]}

For the inflation equation, the distances from $A$ (stable and open) and $B$ (open and sovereign) are significant, whereas the distance from $C$ (stable and sovereign) is not. The common element of points $A$ and $B$ is financial account openness, so it is likely that this aspect of trilemma policies is commensurate with a lower inflation rate. This result provides support for the argument that increased financial account openness generates these conditions that are necessary for inflation to be reigned in.

Other estimations, results of which are not shown because of space limitations, tell a similar story. With regard to the growth equation, the signs and statistical significance of the coefficients of the three distance variables do not change in the static model with country and time effects or the dynamic model with country effects. In contrast, introducing time effects in a dynamic specification, which is then estimated with the two-step Blundell and Bond procedure, renders all coefficients other than investment insignificant. With regard to the inflation equation, the coefficient of Distance from Stable \& Open remains positive and statistically significant in all models other than the dynamic specification with fixed country and time effects - in the latter only the one-period lagged inflation and money growth variables have statistically significant coefficients. The results concerning the coefficient of Distance from Open \& Sovereign are less robust to alternative specifications. Finally, for the inflation equation, the coefficient of Distance from Stable 8 Sovereign is insignificant everywhere. ${ }^{30}$

\footnotetext{
${ }^{30}$ Relaxing strict exogeneity by endogenising investment and money growth in the output growth and inflation equations, respectively, leaves results largely unaltered.
} 
The significance of exchange rate stability and financial account openness is further explored by employing deviations from their 'average' values. Average values here are taken to represent what Popper et al. (2013) label as 'middletype' policy configurations, i.e. configurations where each of the variables has a value of $2 / 3$ and the trilemma constraint is satisfied..$^{31}$ Results are presented under Specification II in Table 5 and confirm the earlier findings. The link between 'above average' exchange rate stability and economic growth is confirmed. In addition, exchange rate stability is also linked to inflation, even though its estimated coefficient is approximately half the size of the coefficient of financial openness.

\section{Conclusions}

The international macroeconomic policy trilemma is now more than half a century old (Mundell, 1963). It has profound implications for open macroeconomic policy, as it sets out clear constraints within which the latter has to operate. Under perfect capital mobility, and assuming asset substitutability, the prevalence of the trilemma is guaranteed by the no-arbitrage condition. But if markets are imperfect, there is scope to examine whether countries' policies are really bound by it.

There have been few such tests in the literature and most of these have appeared in the last decade. This paper proposes a new method for testing the trilemma based on Euclidean geometry. The appeal of this approach is that it is straightforward to implement and easy to visualise. Using annual data between 1970 and 2012 on exchange rate stability, financial account openness and monetary independence for 123 countries, the tests support the policy

\footnotetext{
${ }^{31}$ So, exchange rate stability is calculated as $\frac{s-2 / 3}{\sqrt{3}}$, and so on.
} 
relevance of the trilemma constraint.

But what happens in terms of macroeconomic outcomes when countries' policies deviate from it? Tests indicate that, on average, policy configurations are not on the trilemma constraint, i.e. there is a degree of 'trilemmaineffectiveness'. The paper shows that this has costs in terms of real output growth and price inflation. It also explores the role of each of the trilemma's dimensions and finds that exchange rate stability matters for growth and financial account openness matters for inflation. These results are consistent with Aghion et al. (2009) and Wei and Tytell (2004), respectively.

Following from these results, two policy recommendations could be made: first, to open up the financial account, and, second, to manage the exchange rate so that it does not become excessively volatile. Even though the mechanisms through which these arrangements would affect inflation and output have not been empirically probed in this work, past experience suggests that the benefits of increased foreign investment and international trade may be relevant. Of course, such considerations are not without caveats. Namely, financial account liberalisation needs to be "well planned, timed, and sequenced" (International Monetary Fund, 2012) and exchange rate stability may require the accumulation of international reserves at the expense of other, more productive uses of capital. Even with these caveats in place, there are risks that need to be taken into account when designing international macroeconomic policy along these lines.

This work can be extended in several directions. First, it is important to refine the measurement of the trilemma dimensions. For example, Shambaugh's (2004) approach may need to be modified in order to ensure that common country shocks are not mistaken for increased monetary dependence. Popper et al. (2013) derive an alternative measure of monetary sovereignty but this 
presupposes the validity of the trilemma and, hence, cannot be used to test it. Regarding financial account openness, the use of a de facto measure would be advantageous compared to a de jure measure. Deviations from covered interest parity can be used for this purpose but there are data limitations. Second, improved measurement of the relevant variables should encourage a thorough examination of the trilemma's linearity. Alternative functional forms may be explored. Finally, it would be worthy to identify the precise mechanisms through which improving trilemma effectiveness is linked to better macroeconomic outcomes. 


\section{References}

Aghion, P., Bacchetta, P., Rancière, R., and Rogoff, K. (2009). Exchange rate volatility and productivity growth: The role of financial development. Journal of Monetary Economics, 56(4):494-513.

Aizenman, J. (2013). THE IMPOSSIBLE TRINITY — FROM THE POLICY TRILEMMA TO THE POLICY QUADRILEMMA. Global Journal of Economics, 02(01):1350001.

Aizenman, J., Chinn, M., and Ito, H. (2010). The emerging global financial architecture: Tracing and evaluating new patterns of the trilemma configuration. Journal of International Money and Finance, 29(4):615-641.

Aizenman, J., Chinn, M. D., and Ito, H. (2013). The "Impossible Trinity" Hypothesis in an Era of Global Imbalances: Measurement and Testing. Review of International Economics, 21(3):447-458.

Bleaney, M., Lee, H. A., and Lloyd, T. (2013). Testing the trilemma: exchange rate regimes, capital mobility, and monetary independence. Oxford Economic Papers, 65(4):876-897.

Blundell, R. and Bond, S. (2000). GMM Estimation with persistent panel data: an application to production functions. Econometric Reviews, 19(3):321340.

Bussière, M. and Fratzscher, M. (2008). Financial Openness and Growth: Short-run Gain, Long-run Pain? Review of International Economics, 16(1):69-95.

Calvo, G. and Reinhart, C. M. (2002). Fear of Floating. The Quarterly Journal of Economics, CXVII(2):379-408. 
Calvo, G. A. (1998). Capital Flows and Capital-Market Crises: The Simple Economics of Sudden Stops. Journal of Applied Economics, 0:35-54.

Chinn, M. D. and Ito, H. (2006). What matters for financial development? Capital controls, institutions, and interactions. Journal of Development Economics, 81(1):163-192.

Dreher, A., Sturm, J.-E., and Haan, J. d. (2010). When is a central bank governor replaced? Evidence based on a new data set. Journal of Macroeconomics, Elsevier, 32(3):766-781.

Globan, T. (2014). Testing the 'trilemma' in post-transition Europe - a new empirical measure of capital mobility. Post-Communist Economies, 26(4):459-476.

Herring, R. J. and Marston, R. C. (1977). Sterilization policy: The tradeoff between monetary autonomy and control over foreign exchange reserves. European Economic Review, 10(3):325 - 343.

Husain, A., Mody, A., and Rogoff, K. S. (2005). Exchange rate regime durability and performance in developing versus advanced economies. Journal of Monetary Economics, 52:35-64.

International Monetary Fund (2012). The Liberalization and Management of Capital Flows - An Institutional View. Policy Paper.

Klein, M. W. and Olivei, G. P. (2008). Capital account liberalization, financial depth, and economic growth. Journal of International Money and Finance, $27(6): 861-875$.

Kose, M. A., Prasad, E., Rogoff, K., and Wei, S.-J. (2009). Financial Globalization: A Reappraisal. IMF Staff Papers, 56(1):8-62. 
Mundell, R. A. (1963). Capital mobility and stabilization policy under fixed and flexible exchange rates. The Canadian Journal of Economics and Political Science / Revue canadienne d'Economique et de Science politique, 29(4):pp. 475-485.

Nichols, A. and Schaffer, M. E. (2007). Clustered standard errors in Stata. United Kingdom Stata Users' Group Meetings 2007 07, Stata Users Group.

Obstfeld, M., Shambaugh, J., and Taylor, A. (2005). THE TRILEMMA IN HISTORY: TRADEOFFS AMONG EXCHANGE RATES, MONETARY POLICIES, AND CAPITAL MOBILITY . Review of Economics and Statistics, $87(3): 423-438$.

Popper, H., Mandilaras, A., and Bird, G. (2013). Trilemma stability and international macroeconomic archetypes. European Economic Review, 64:181193.

Rey, H. (2013). Dilemma not trilemma: the global cycle and monetary policy independence. Proceedings - Economic Policy Symposium - Jackson Hole, pages $1-2$.

Schaffer, M. E. and Stillman, S. (2006). XTOVERID: Stata module to calculate tests of overidentifying restrictions after xtreg, xtivreg, xtivreg2, xthtaylor. Statistical Software Components, Boston College Department of Economics.

Shambaugh, J. (2004). The Effect of Fixed Exchange Rates on Monetary Policy. Quarterly Journal of Economics, 119(1):300-351.

Steiner, A. (2013). The accumulation of foreign exchange by central banks: Fear of capital mobility? Journal of Macroeconomics, 38:409-427. 
Wei, S.-J. and Tytell, I. (2004). Does Financial Globalization Induce Better Macroeconomic Policies? IMF Working Papers 04/84, International Monetary Fund. 
Table 1: Trilemma Distance

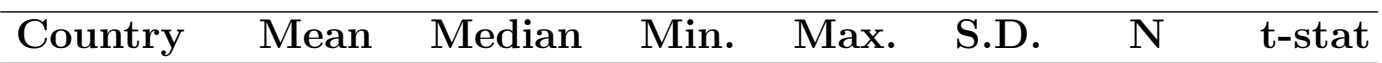

Panel A: Income Groups

\begin{tabular}{llllllll}
\hline All & -0.28 & -0.27 & -0.99 & 0.42 & 0.26 & 5289 & $-79.8^{*}$ \\
LIC & -0.39 & -0.38 & -0.96 & 0.33 & 0.23 & 1181 & $-58.3^{*}$ \\
MIC & -0.28 & -0.28 & -0.99 & 0.42 & 0.27 & 2581 & $-54.1^{*}$ \\
HIC & -0.21 & -0.19 & -0.98 & 0.41 & 0.24 & 1527 & $-33.3^{*}$ \\
\hline
\end{tabular}

Panel B: Geographical Regions

\begin{tabular}{llllllll}
\hline EAP & -0.37 & -0.39 & -0.85 & 0.35 & 0.24 & 473 & $-33.8^{*}$ \\
ECA & -0.35 & -0.36 & -0.98 & 0.29 & 0.23 & 268 & $-25.1^{*}$ \\
LAC & -0.21 & -0.20 & -0.99 & 0.39 & 0.28 & 940 & $-22.4^{*}$ \\
MENA & -0.29 & -0.34 & -0.85 & 0.42 & 0.30 & 332 & $-17.5^{*}$ \\
SA & -0.36 & -0.39 & -0.83 & 0.39 & 0.25 & 255 & $-23.4^{*}$ \\
SSA & -0.36 & -0.32 & -0.96 & 0.33 & 0.22 & 1494 & $-62.0^{*}$ \\
\hline
\end{tabular}

Panel C: Decades

\begin{tabular}{llllllrl}
\hline $1970 \mathrm{~s}$ & -0.31 & -0.29 & -0.98 & 0.32 & 0.23 & 858 & $-39.0^{*}$ \\
$1980 \mathrm{~s}$ & -0.34 & -0.32 & -0.99 & 0.33 & 0.26 & 1175 & $-45.1^{*}$ \\
$1990 \mathrm{~s}$ & -0.28 & -0.26 & -0.98 & 0.42 & 0.27 & 1479 & $-40.2^{*}$ \\
$2000 \mathrm{~s}$ & -0.23 & -0.22 & -0.96 & 0.39 & 0.25 & 1777 & $-39.4^{*}$ \\
\hline \hline
\end{tabular}

Notes: $H_{0}:$ Mean $=0, H_{1}:$ Mean $>0$. A "*" indicates that $H_{0}$ cannot be rejected at the $5 \%$ level. A minus sign ' -' signifies direction. Definitions of income groups: LIC: lowincome countries; MIC: middle-income countries; HIC: high-income countries. Definition of geographical regions: EAP: East Asia and the Pacific; ECA: Europe and Central Asia; LAC: Latin America and the Caribbean; MENA: Middle East and North Africa; SA: South Asia; SSA: Sub-Saharan Africa. 


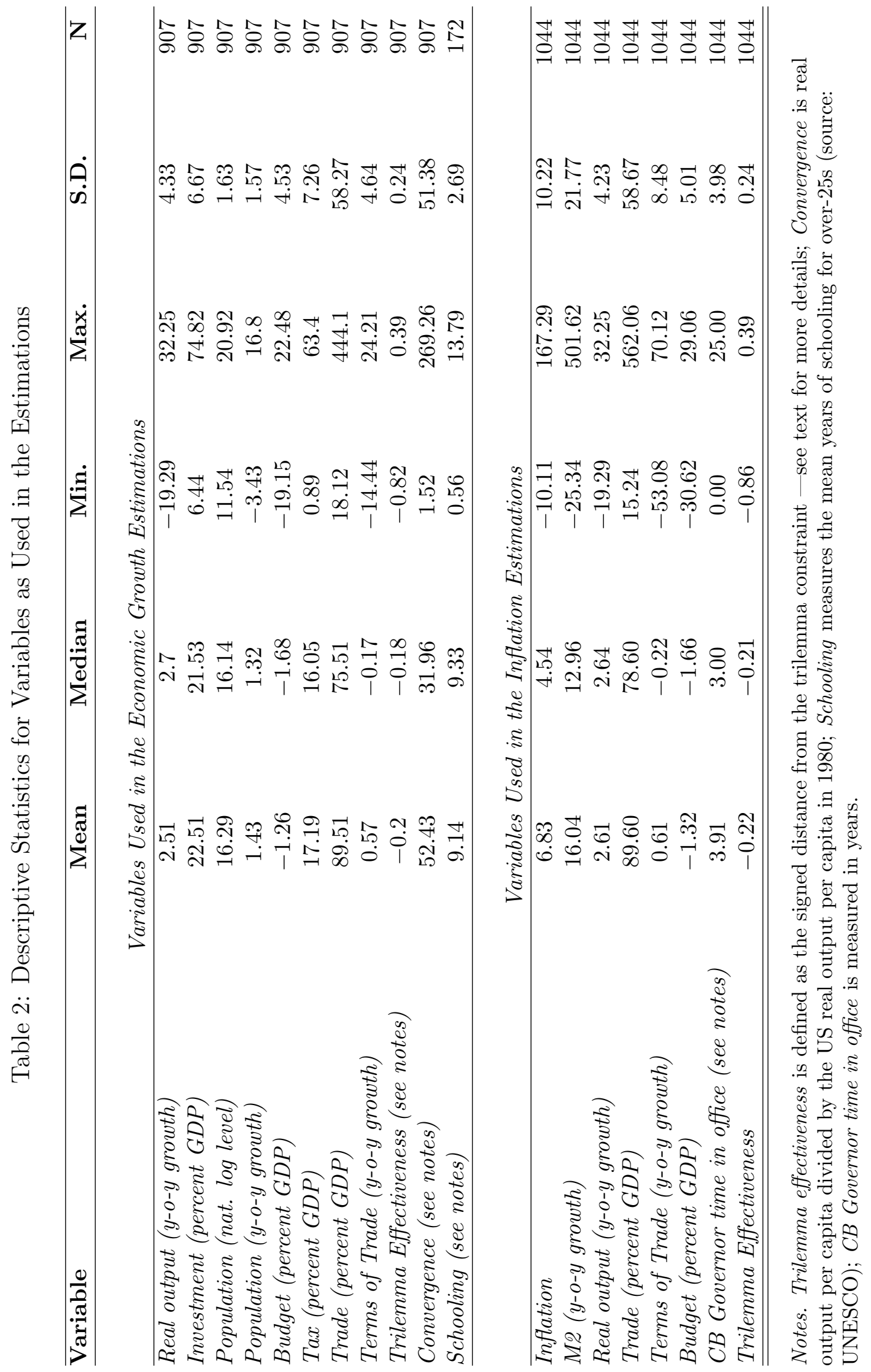




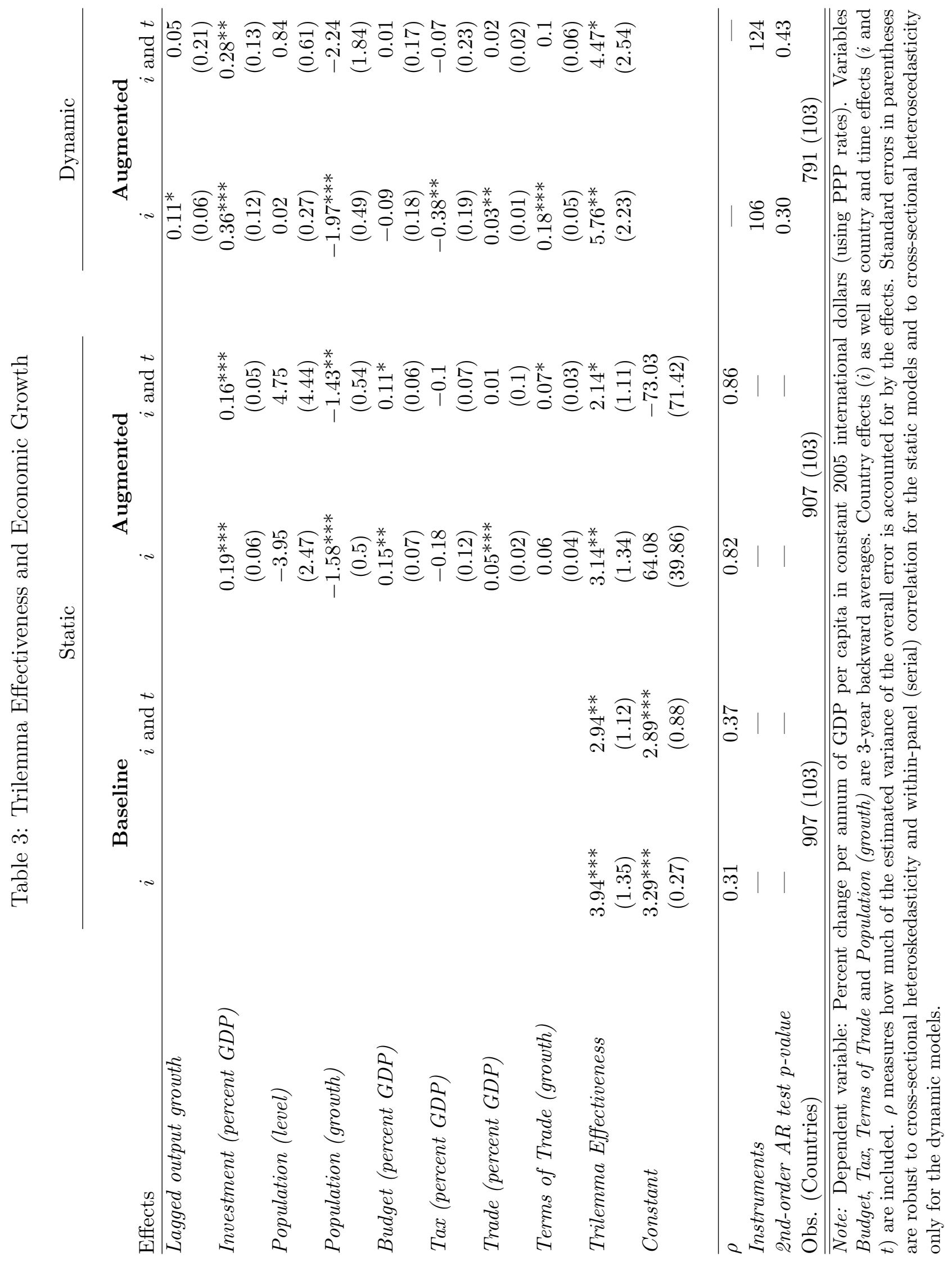




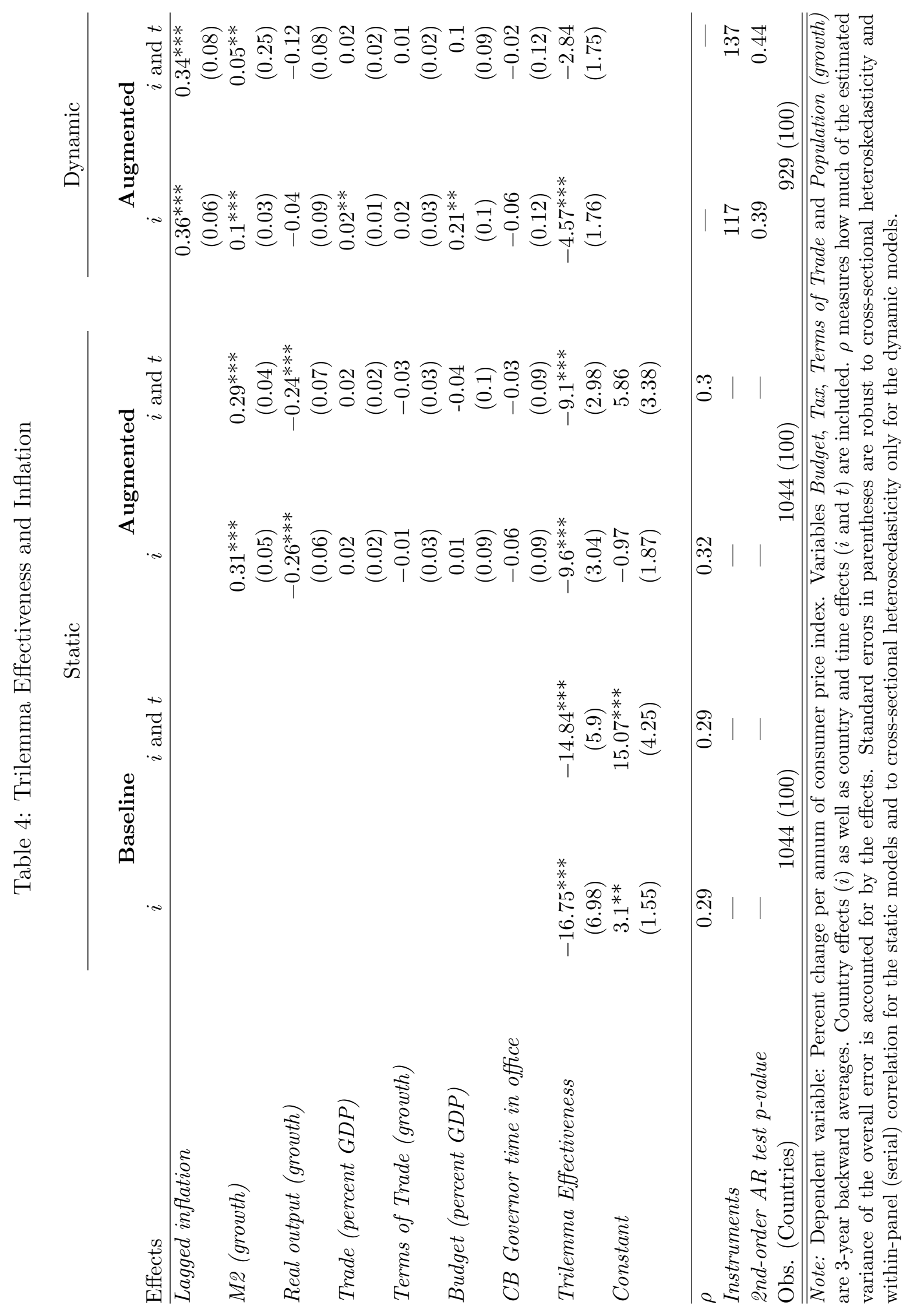


Table 5: Stable, Open, Sovereign: Which Ones Matter?

\begin{tabular}{|c|c|c|c|c|}
\hline & \multicolumn{2}{|c|}{ Specification I } & \multicolumn{2}{|c|}{ Specification II } \\
\hline & Coeff. & St. Err. & Coeff. & St. Err \\
\hline \multicolumn{5}{|l|}{ Economic Growth Equation } \\
\hline Investment (percent GDP) & $0.21^{* * *}$ & $(0.07)$ & $0.21^{* * *}$ & $(0.07)$ \\
\hline Population (level) & -2.13 & $(2.50)$ & $-2.10^{* * *}$ & $(2.51)$ \\
\hline Population (growth) & $-1.65^{* * *}$ & $(0.50)$ & -1.70 & $(0.50)$ \\
\hline Budget (percent GDP) & $0.13^{*}$ & $(0.08)$ & $0.15^{* *}$ & $(0.08)$ \\
\hline Tax (percent GDP) & -0.17 & $(0.11)$ & -0.15 & $(0.11)$ \\
\hline Trade (percent GDP) & $0.05^{* * *}$ & $(0.02)$ & 0.05 & $(0.02)$ \\
\hline Terms of Trade (growth) & $0.06^{*}$ & $(0.03)$ & $0.05^{* * *}$ & $(0.04)$ \\
\hline Distance from Stable \& Open & $-4.81^{* * *}$ & $(1.12)$ & & \\
\hline Distance from Open $\&$ Sovereign & -1.40 & $(1.28)$ & & \\
\hline Distance from Stable \& Sovereign & $-6.52^{* * *}$ & $(1.19)$ & & \\
\hline Exchange Rate Stability Deviation & & & $7.71^{* * *}$ & $(1.87)$ \\
\hline Financial Openness Deviation & & & -3.46 & $(2.27)$ \\
\hline Monetary Independence Deviation & & & 1.46 & $(1.81)$ \\
\hline Constant & 45.20 & $(40.33)$ & 33.12 & $(40.47)$ \\
\hline \multicolumn{5}{|l|}{ Inflation Equation } \\
\hline M2 (growth) & $0.07^{* * *}$ & $(0.01)$ & $0.31^{* * *}$ & $(0.05)$ \\
\hline Real output (growth) & $-0.20^{* * *}$ & $(0.07)$ & $-0.25^{* * *}$ & $(0.06)$ \\
\hline Trade (percent GDP) & 0.02 & $(0.02)$ & 0.02 & $(0.02)$ \\
\hline Terms of Trade (growth) & 0.03 & $(0.04)$ & -0.01 & $(0.03)$ \\
\hline Budget (percent GDP) & $0.22^{* *}$ & $(0.10)$ & 0.01 & $(0.09)$ \\
\hline$C B$ Governor time in office & -0.20 & $(0.15)$ & 0.01 & $(0.09)$ \\
\hline Distance from Stable $\&$ Open & $29.33^{* *}$ & $(14.65)$ & & \\
\hline Distance from Open 85 Sovereign & $23.79 *$ & $(13.15)$ & & \\
\hline Distance from Stable \& Sovereign & 11.34 & $(9.34)$ & & \\
\hline Exchange Rate Stability Deviation & & & $-8.87^{* * *}$ & $(3.22)$ \\
\hline Financial Openness Deviation & & & $-19.04^{* * *}$ & $(6.90)$ \\
\hline Monetary Independence Deviation & & & 0.28 & $(3.57)$ \\
\hline Constant & -52.32 & $(32.22)$ & 0.01 & $(1.92)$ \\
\hline
\end{tabular}

Note: Least squares dummy variables estimation with country effects. Standard errors in parentheses are robust to cross-sectional heteroskedasticity and within-panel (serial) correlation. For information on the variables see notes of Tables 3 and 4 , as well as Section 4.4 


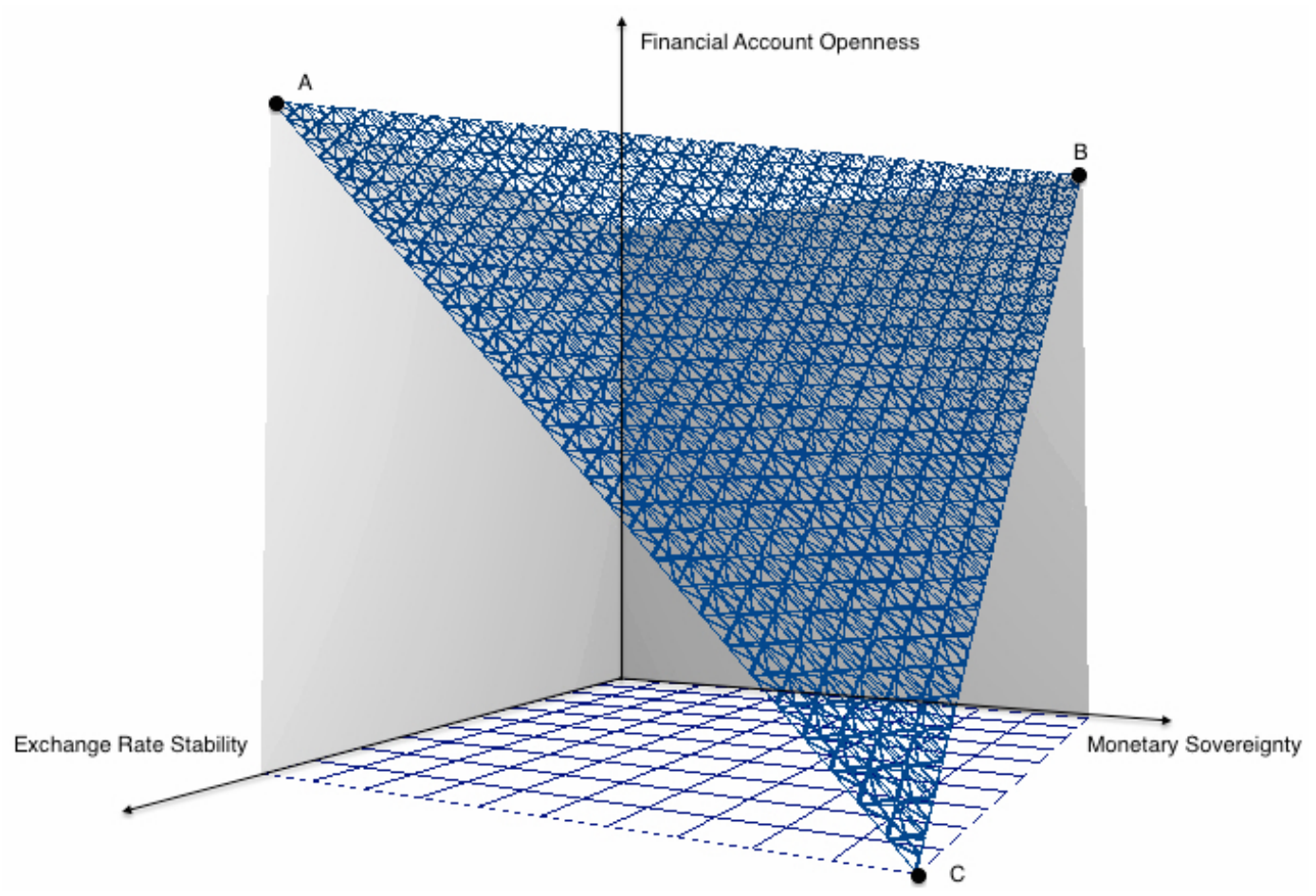

Figure 1: The Trilemma Constraint 


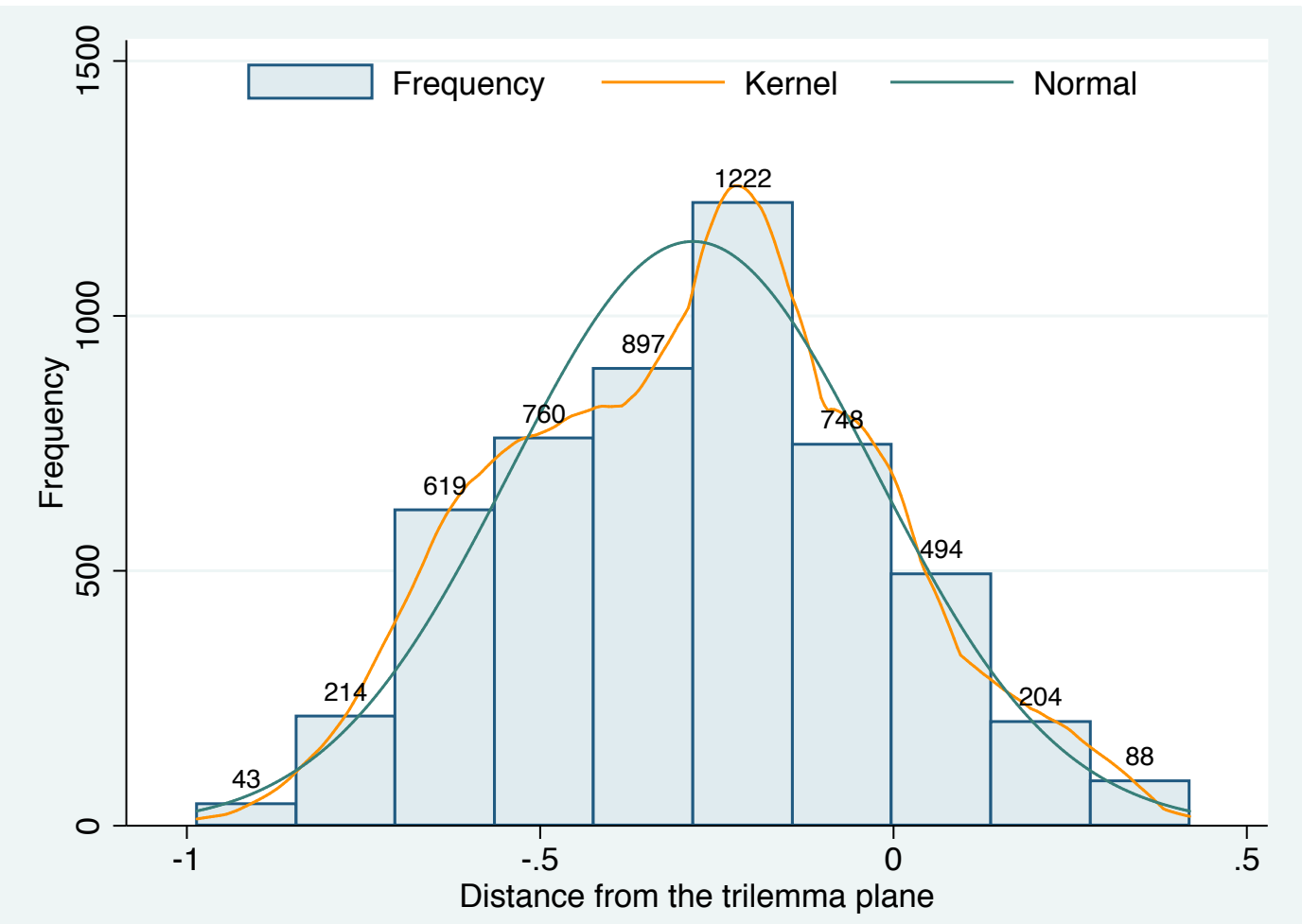

Figure 2: Histogram and Densities of Trilemma Distance 

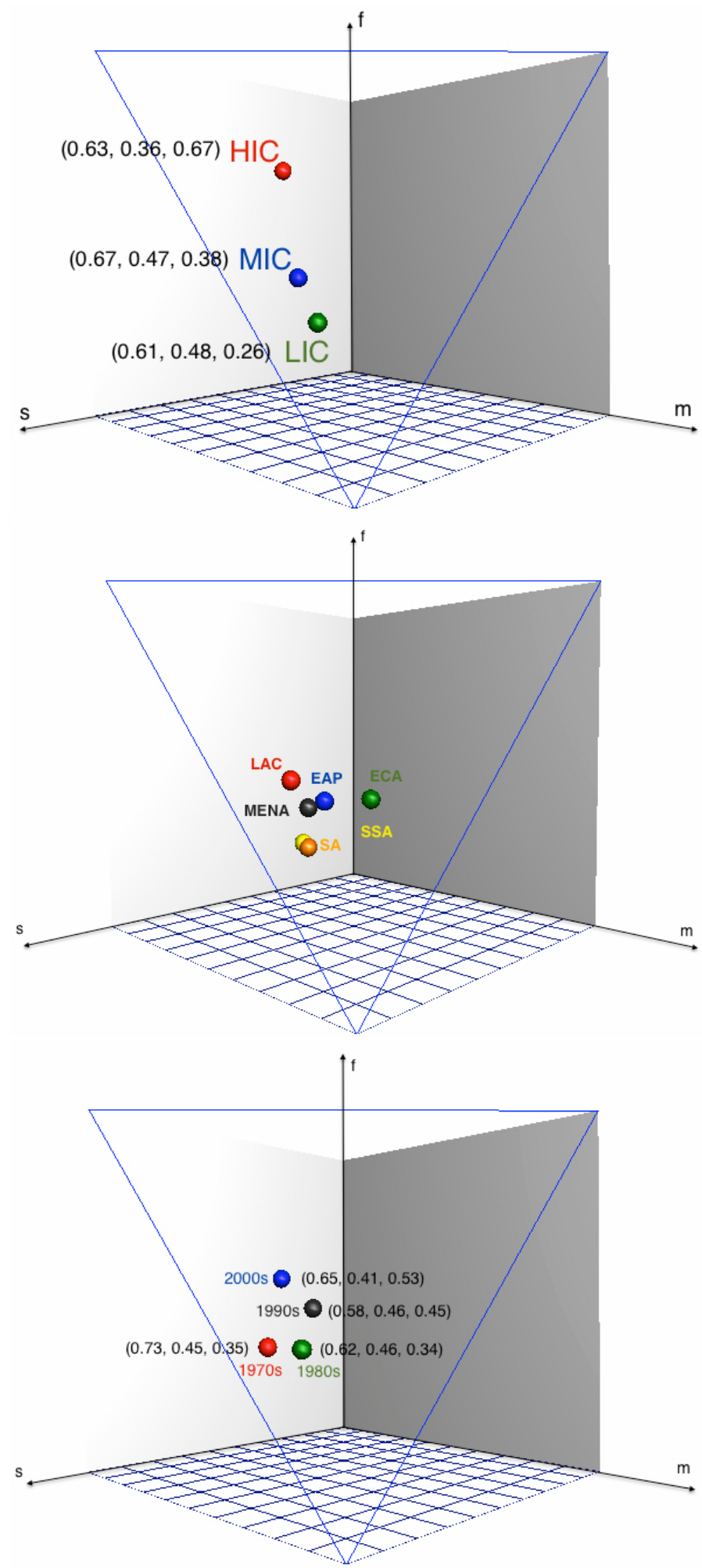

Figure 3: Trilemma Policy Choices: by Income (top graph), by Geographical Region (middle graph) and by Decade (bottom graph). Exchange rate stability, monetary independence and financial account openness in parentheses. 


\section{A Appendix}

Table A1: Trilemma Distance by Country

\begin{tabular}{|c|c|c|c|c|c|c|c|}
\hline Country & Mean & Median & Min & Max & SD & $\mathbf{N}$ & t-stat \\
\hline Albania & -0.45 & -0.42 & -0.71 & -0.21 & 0.15 & 17 & $-12.3^{*}$ \\
\hline Algeria & -0.61 & -0.63 & -0.74 & -0.39 & 0.09 & 38 & $-41.1^{*}$ \\
\hline Angola & -0.63 & -0.62 & -0.84 & -0.18 & 0.21 & 17 & $-12.5^{*}$ \\
\hline Antigua & 0.20 & 0.19 & -0.04 & 0.29 & 0.10 & 25 & 10.2 \\
\hline Argentina & -0.41 & -0.49 & -0.89 & 0.28 & 0.35 & 35 & $-6.7^{*}$ \\
\hline Armenia & -0.10 & -0.09 & -0.43 & 0.19 & 0.15 & 16 & $-2.6^{*}$ \\
\hline Aruba & -0.17 & -0.20 & -0.28 & -0.05 & 0.08 & 18 & $-9.3^{*}$ \\
\hline Australia & -0.33 & -0.34 & -0.66 & -0.03 & 0.15 & 42 & $-14.2^{*}$ \\
\hline Austria & -0.09 & -0.05 & -0.33 & 0.03 & 0.10 & 42 & $-5.6^{*}$ \\
\hline Azerbaijan & -0.29 & -0.32 & -0.55 & 0 & 0.15 & 16 & $-8.0^{*}$ \\
\hline Bahamas, The & -0.21 & -0.25 & -0.39 & 0.15 & 0.12 & 35 & $-10.7^{*}$ \\
\hline Bahrain & 0.14 & 0.13 & -0.01 & 0.37 & 0.09 & 35 & 8.5 \\
\hline Bangladesh & -0.46 & -0.46 & -0.79 & 0.04 & 0.21 & 36 & $-13.0^{*}$ \\
\hline Barbados & -0.21 & -0.17 & -0.69 & 0.04 & 0.15 & 38 & $-9.0^{*}$ \\
\hline Belarus & -0.50 & -0.55 & -0.98 & 0.03 & 0.30 & 16 & $-6.7^{*}$ \\
\hline Belgium & -0.10 & -0.06 & -0.47 & 0.08 & 0.12 & 42 & $-5.4^{*}$ \\
\hline Belize & -0.15 & -0.17 & -0.33 & 0.02 & 0.11 & 27 & $-7.0^{*}$ \\
\hline Benin & -0.18 & -0.20 & -0.33 & -0.05 & 0.08 & 33 & $-12.7^{*}$ \\
\hline Bhutan & -0.22 & -0.20 & -0.41 & -0.17 & 0.06 & 25 & $-17.7^{*}$ \\
\hline Bolivia & -0.07 & 0.04 & -0.91 & 0.23 & 0.29 & 41 & $-1.4^{*}$ \\
\hline Botswana & -0.36 & -0.33 & -0.72 & -0.06 & 0.19 & 36 & $-11.5^{*}$ \\
\hline Brazil & -0.59 & -0.58 & -0.98 & -0.19 & 0.17 & 42 & $-22.9^{*}$ \\
\hline Bulgaria & -0.22 & -0.23 & -0.74 & 0.29 & 0.33 & 18 & $-2.8^{*}$ \\
\hline Burkina Faso & -0.16 & -0.16 & -0.33 & -0.02 & 0.09 & 24 & $-8.57^{*}$ \\
\hline Burundi & -0.52 & -0.57 & -0.82 & -0.20 & 0.17 & 35 & $-17.91^{*}$ \\
\hline Cambodia & -0.33 & -0.29 & -0.78 & 0.04 & 0.23 & 17 & $-5.9^{*}$ \\
\hline Cameroon & -0.19 & -0.21 & -0.53 & 0.02 & 0.12 & 42 & $-10.2^{*}$ \\
\hline
\end{tabular}


Table A1 - continued from previous page

\begin{tabular}{|c|c|c|c|c|c|c|c|}
\hline Country & Mean & Median & Min & Max & SD & $\mathbf{N}$ & t-stat \\
\hline Canada & -0.14 & -0.15 & -0.35 & 0.07 & 0.09 & 42 & $-10.4^{*}$ \\
\hline Cape Verde & -0.37 & -0.47 & -0.62 & -0.09 & 0.18 & 27 & $-10.6^{*}$ \\
\hline Central African & -0.22 & -0.23 & -0.53 & -0.05 & 0.10 & 42 & $-14.0^{*}$ \\
\hline Chad & -0.23 & -0.24 & -0.53 & -0.05 & 0.10 & 42 & $-14.5^{*}$ \\
\hline Chile & -0.44 & -0.49 & -0.85 & -0.01 & 0.21 & 35 & $-12.3^{*}$ \\
\hline China & -0.34 & -0.29 & -0.65 & -0.12 & 0.15 & 28 & $-11.6^{*}$ \\
\hline Colombia & -0.45 & -0.45 & -0.78 & -0.18 & 0.15 & 42 & $-19.8^{*}$ \\
\hline Comoros & -0.35 & -0.41 & -0.48 & -0.20 & 0.12 & 20 & $-12.9^{*}$ \\
\hline Congo, Dem. Rep. & -0.67 & -0.66 & -0.92 & -0.39 & 0.14 & 25 & $-23.5^{*}$ \\
\hline Congo, Rep. & -0.23 & -0.23 & -0.41 & -0.05 & 0.10 & 42 & $-15.0^{*}$ \\
\hline Costa Rica & -0.20 & -0.11 & -0.78 & 0.30 & 0.28 & 42 & $-4.6^{*}$ \\
\hline Côte d'Ivoire & -0.22 & -0.21 & -0.50 & 0.01 & 0.11 & 42 & $-13.1^{*}$ \\
\hline Croatia & -0.22 & -0.21 & -0.38 & -0.13 & 0.06 & 16 & $-13.7^{*}$ \\
\hline Cyprus & -0.40 & -0.49 & -0.65 & 0.01 & 0.21 & 42 & $-12.5^{*}$ \\
\hline Czech Republic & -0.19 & -0.19 & -0.42 & 0 & 0.13 & 16 & $-5.9^{*}$ \\
\hline Denmark & -0.16 & -0.10 & -0.50 & 0.17 & 0.22 & 42 & $-4.6^{*}$ \\
\hline Djibouti & 0.21 & 0.19 & 0.04 & 0.42 & 0.13 & 16 & 6.6 \\
\hline Dominica & -0.10 & -0.05 & -0.27 & 0.14 & 0.09 & 30 & $-6.4^{*}$ \\
\hline Dominican Republic & -0.31 & -0.35 & -0.72 & 0.18 & 0.30 & 17 & $-4.2^{*}$ \\
\hline Ecuador & -0.17 & -0.05 & -0.67 & 0.29 & 0.30 & 39 & $-3.5^{*}$ \\
\hline Egypt, Arab Rep. & -0.21 & -0.29 & -0.85 & 0.22 & 0.25 & 42 & $-5.3^{*}$ \\
\hline El Salvador & -0.00 & 0.12 & -0.82 & 0.39 & 0.32 & 29 & $-0.1^{*}$ \\
\hline Equatorial Guinea & -0.24 & -0.26 & -0.39 & -0.07 & 0.08 & 27 & $-15.6^{*}$ \\
\hline Estonia & 0.00 & 0.06 & -0.38 & 0.18 & 0.17 & 16 & $0.1^{*}$ \\
\hline Ethiopia & -0.29 & -0.20 & -0.72 & -0.13 & 0.17 & 24 & $-8.5^{*}$ \\
\hline Fiji & -0.53 & -0.53 & -0.78 & -0.29 & 0.14 & 35 & $-23.4^{*}$ \\
\hline Finland & -0.19 & -0.21 & -0.53 & 0.07 & 0.17 & 42 & $-7.5^{*}$ \\
\hline France & -0.27 & -0.26 & -0.72 & 0.07 & 0.25 & 42 & $-7.1^{*}$ \\
\hline
\end{tabular}


Table A1 - continued from previous page

\begin{tabular}{|c|c|c|c|c|c|c|c|}
\hline Country & Mean & Median & Min & Max & SD & $\mathbf{N}$ & t-stat \\
\hline Gabon & -0.17 & -0.14 & -0.53 & 0.03 & 0.12 & 42 & $-9.3^{*}$ \\
\hline Gambia, The & -0.23 & -0.22 & -0.63 & -0.04 & 0.14 & 35 & $-10.0^{*}$ \\
\hline Georgia & -0.24 & -0.25 & -0.56 & 0.03 & 0.16 & 16 & $-6.0^{*}$ \\
\hline Germany & -0.19 & -0.20 & -0.40 & 0.17 & 0.13 & 42 & $-9.6^{*}$ \\
\hline Ghana & -0.45 & -0.43 & -0.87 & -0.08 & 0.22 & 42 & $-13.0^{*}$ \\
\hline Greece & -0.34 & -0.40 & -0.79 & 0.04 & 0.26 & 42 & $-8.6^{*}$ \\
\hline Grenada & -0.23 & -0.27 & -0.38 & -0.05 & 0.08 & 31 & $-15.3^{*}$ \\
\hline Guatemala & -0.10 & -0.13 & -0.61 & 0.32 & 0.22 & 41 & $-2.9^{*}$ \\
\hline Guinea & -0.54 & -0.48 & -0.96 & -0.12 & 0.20 & 21 & $-12.2^{*}$ \\
\hline Guinea-Bissau & -0.64 & -0.63 & -0.85 & -0.42 & 0.09 & 31 & $-38.8^{*}$ \\
\hline Guyana & -0.17 & -0.20 & -0.81 & 0.28 & 0.27 & 42 & $-4.0^{*}$ \\
\hline Haiti & -0.29 & -0.30 & -0.84 & 0.13 & 0.26 & 18 & $-4.8^{*}$ \\
\hline Honduras & -0.16 & -0.20 & -0.74 & 0.25 & 0.23 & 33 & $-4.0^{*}$ \\
\hline Hong Kong, China & 0.15 & 0.18 & -0.24 & 0.37 & 0.13 & 30 & 6.4 \\
\hline Hungary & -0.36 & -0.33 & -0.84 & 0.08 & 0.28 & 26 & $-6.6^{*}$ \\
\hline Iceland & -0.51 & -0.57 & -0.98 & -0.10 & 0.21 & 42 & $-15.8^{*}$ \\
\hline India & -0.51 & -0.53 & -0.80 & -0.22 & 0.14 & 42 & $-23.8^{*}$ \\
\hline Indonesia & -0.16 & -0.27 & -0.52 & 0.22 & 0.26 & 29 & $-3.4^{*}$ \\
\hline Iran, Islamic Republic & -0.17 & -0.24 & -0.43 & 0.21 & 0.20 & 19 & $-3.6^{*}$ \\
\hline Ireland & -0.19 & -0.17 & -0.65 & 0.03 & 0.19 & 42 & $-6.5^{*}$ \\
\hline Israel & -0.38 & -0.42 & -0.78 & -0.03 & 0.22 & 30 & $-9.5^{*}$ \\
\hline Italy & -0.30 & -0.31 & -0.95 & 0.19 & 0.31 & 42 & $-6.3^{*}$ \\
\hline Jamaica & -0.23 & -0.22 & -0.96 & 0.19 & 0.27 & 42 & $-5.7^{*}$ \\
\hline Japan & -0.20 & -0.21 & -0.46 & -0.01 & 0.10 & 42 & $-12.7^{*}$ \\
\hline Jordan & -0.18 & -0.26 & -0.64 & 0.39 & 0.31 & 42 & $-3.8^{*}$ \\
\hline Kazakhstan & -0.37 & -0.33 & -0.69 & -0.17 & 0.13 & 16 & $-11.9^{*}$ \\
\hline Kenya & -0.40 & -0.42 & -0.74 & -0.04 & 0.20 & 42 & $-12.5^{*}$ \\
\hline Korea, Rep. & -0.38 & -0.39 & -0.79 & -0.12 & 0.18 & 42 & $-13.8^{*}$ \\
\hline
\end{tabular}


Table A1 - continued from previous page

\begin{tabular}{|c|c|c|c|c|c|c|c|}
\hline Country & Mean & Median & Min & $\operatorname{Max}$ & SD & $\mathbf{N}$ & t-stat \\
\hline Kuwait & -0.08 & -0.08 & -0.30 & 0.14 & 0.11 & 37 & $-4.5^{*}$ \\
\hline Kyrgyzstan & -0.11 & -0.10 & -0.33 & 0.05 & 0.10 & 15 & $-4.5^{*}$ \\
\hline Lao PDR & -0.47 & -0.47 & -0.85 & -0.20 & 0.18 & 30 & $-13.9^{*}$ \\
\hline Latvia & -0.06 & -0.05 & -0.32 & 0.13 & 0.12 & 16 & $-2.1^{*}$ \\
\hline Lebanon & -0.04 & -0.02 & -0.35 & 0.38 & 0.21 & 42 & $-1.1^{*}$ \\
\hline Lesotho & -0.31 & -0.32 & -0.47 & -0.06 & 0.11 & 32 & $-15.6^{*}$ \\
\hline Liberia & -0.03 & -0.07 & -0.46 & 0.33 & 0.19 & 29 & $-0.8^{*}$ \\
\hline Libya & -0.42 & -0.53 & -0.75 & -0.05 & 0.23 & 33 & $-10.5^{*}$ \\
\hline Lithuania & -0.19 & -0.17 & -0.37 & -0.06 & 0.08 & 16 & $-9.3^{*}$ \\
\hline Madagascar & -0.48 & -0.52 & -0.76 & -0.18 & 0.19 & 40 & $-16.2^{*}$ \\
\hline Malawi & -0.53 & -0.59 & -0.87 & -0.09 & 0.18 & 42 & $-18.7^{*}$ \\
\hline Malaysia & -0.21 & -0.16 & -0.57 & 0.18 & 0.19 & 42 & $-7.2^{*}$ \\
\hline Maldives & 0.06 & 0.13 & -0.39 & 0.39 & 0.26 & 30 & $1.1^{*}$ \\
\hline Mali & -0.20 & -0.20 & -0.43 & 0.01 & 0.11 & 42 & $-11.7^{*}$ \\
\hline Malta & -0.46 & -0.55 & -0.69 & 0.02 & 0.22 & 40 & $-13.1^{*}$ \\
\hline Mauritania & -0.50 & -0.53 & -0.76 & -0.20 & 0.13 & 41 & $-23.6^{*}$ \\
\hline Mauritius & -0.42 & -0.33 & -0.78 & -0.07 & 0.22 & 40 & $-12.0^{*}$ \\
\hline Mexico & -0.29 & -0.31 & -0.61 & 0.22 & 0.22 & 36 & $-7.8^{*}$ \\
\hline Micronesia, Fed. & 0.12 & 0.10 & -0.13 & 0.35 & 0.16 & 16 & 3.0 \\
\hline Moldova & -0.46 & -0.48 & -0.57 & -0.33 & 0.07 & 16 & $-28.3^{*}$ \\
\hline Mongolia & -0.19 & -0.18 & -0.41 & 0 & 0.13 & 17 & $-6.2^{*}$ \\
\hline Morocco & -0.50 & -0.48 & -0.72 & -0.26 & 0.10 & 40 & $-31.2^{*}$ \\
\hline Mozambique & -0.62 & -0.62 & -0.85 & -0.35 & 0.17 & 18 & $-15.8^{*}$ \\
\hline Myanmar & -0.58 & -0.58 & -0.71 & -0.45 & 0.07 & 37 & $-50.4^{*}$ \\
\hline Namibia & -0.42 & -0.45 & -0.58 & -0.26 & 0.08 & 18 & $-22.9^{*}$ \\
\hline Nepal & -0.39 & -0.41 & -0.83 & -0.03 & 0.17 & 38 & $-14.4^{*}$ \\
\hline Netherlands & -0.05 & 0 & -0.46 & 0.16 & 0.14 & 36 & $-2.0^{*}$ \\
\hline New Zealand & -0.32 & -0.32 & -0.69 & -0.07 & 0.15 & 42 & $-13.7^{*}$ \\
\hline
\end{tabular}


Table A1 - continued from previous page

\begin{tabular}{|c|c|c|c|c|c|c|c|}
\hline Country & Mean & Median & Min & Max & SD & $\mathbf{N}$ & t-stat \\
\hline Nicaragua & 0.09 & 0.19 & -0.62 & 0.39 & 0.28 & 22 & $1.5^{*}$ \\
\hline Niger & -0.22 & -0.19 & -0.53 & 0.01 & 0.13 & 42 & $-10.7^{*}$ \\
\hline Nigeria & -0.45 & -0.47 & -0.77 & -0.05 & 0.19 & 42 & $-15.3^{*}$ \\
\hline Norway & -0.31 & -0.29 & -0.55 & -0.05 & 0.14 & 42 & $-14.7^{*}$ \\
\hline Oman & 0.20 & 0.23 & 0.01 & 0.29 & 0.09 & 32 & 13.0 \\
\hline Pakistan & -0.39 & -0.38 & -0.71 & -0.01 & 0.18 & 42 & $-14.0^{*}$ \\
\hline Panama & 0.17 & 0.16 & 0.02 & 0.38 & 0.10 & 26 & 8.6 \\
\hline Papua New Guinea & -0.42 & -0.46 & -0.63 & -0.07 & 0.16 & 33 & $-15.0^{*}$ \\
\hline Paraguay & -0.29 & -0.27 & -0.70 & 0.04 & 0.14 & 22 & $-9.4^{*}$ \\
\hline Peru & -0.32 & -0.22 & -0.99 & 0.08 & 0.31 & 42 & $-6.7^{*}$ \\
\hline Philippines & -0.42 & -0.42 & -0.85 & -0.12 & 0.18 & 42 & $-15.5^{*}$ \\
\hline Poland & -0.64 & -0.68 & -0.86 & -0.37 & 0.14 & 21 & $-21.0^{*}$ \\
\hline Portugal & -0.28 & -0.33 & -0.64 & 0.19 & 0.25 & 42 & $-7.2^{*}$ \\
\hline Qatar & 0.21 & 0.23 & 0.01 & 0.35 & 0.10 & 31 & 11.3 \\
\hline Romania & -0.32 & -0.34 & -0.72 & -0.02 & 0.23 & 18 & $-5.9^{*}$ \\
\hline Russian Federation & -0.35 & -0.36 & -0.64 & -0.16 & 0.13 & 16 & $-10.3^{*}$ \\
\hline Rwanda & -0.47 & -0.49 & -0.75 & -0.11 & 0.16 & 42 & $-19.0^{*}$ \\
\hline Samoa & -0.61 & -0.60 & -0.81 & -0.35 & 0.12 & 29 & $-26.1^{*}$ \\
\hline São Tomé and Príncipe & -0.50 & -0.49 & -0.85 & -0.17 & 0.20 & 24 & $-12.3^{*}$ \\
\hline Saudi Arabia & -0.06 & -0.14 & -0.16 & 0.14 & 0.11 & 15 & $-2.2^{*}$ \\
\hline Senegal & -0.19 & -0.20 & -0.41 & 0.01 & 0.10 & 42 & $-11.8^{*}$ \\
\hline Seychelles & -0.16 & -0.15 & -0.44 & 0.07 & 0.14 & 31 & $-6.4^{*}$ \\
\hline Sierra Leone & -0.47 & -0.50 & -0.84 & -0.17 & 0.20 & 41 & $-15.1^{*}$ \\
\hline Singapore & -0.07 & -0.05 & -0.39 & 0.19 & 0.13 & 40 & $-3.2^{*}$ \\
\hline Slovak Republic & -0.40 & -0.42 & -0.65 & -0.14 & 0.16 & 16 & $-10.0^{*}$ \\
\hline Slovenia & -0.16 & -0.14 & -0.56 & 0.11 & 0.18 & 16 & $-3.6^{*}$ \\
\hline Solomon Islands & -0.35 & -0.32 & -0.81 & -0.09 & 0.18 & 30 & $-10.9^{*}$ \\
\hline South Africa & -0.56 & -0.59 & -0.95 & -0.04 & 0.22 & 42 & $-16.3^{*}$ \\
\hline
\end{tabular}


Table A1 - continued from previous page

\begin{tabular}{|c|c|c|c|c|c|c|c|}
\hline Country & Mean & Median & Min & Max & SD & $\mathbf{N}$ & t-stat \\
\hline Spain & -0.25 & -0.31 & -0.65 & 0.17 & 0.23 & 42 & $-7.2^{*}$ \\
\hline Sri Lanka & -0.45 & -0.44 & -0.83 & -0.08 & 0.17 & 42 & $-16.9^{*}$ \\
\hline St. Kitts \& Nevis & -0.16 & -0.17 & -0.38 & -0.05 & 0.10 & 24 & $-8.2^{*}$ \\
\hline St. Lucia & -0.11 & -0.10 & -0.24 & 0.01 & 0.07 & 29 & $-8.1^{*}$ \\
\hline St.Vincent \& Grenadines & -0.16 & -0.20 & -0.38 & -0.05 & 0.10 & 29 & $-9.2^{*}$ \\
\hline Sudan & -0.26 & -0.29 & -0.29 & -0.22 & 0.04 & 7 & $-18.4^{*}$ \\
\hline Suriname & -0.37 & -0.29 & -0.95 & -0.03 & 0.26 & 21 & $-6.5^{*}$ \\
\hline Swaziland & -0.29 & -0.30 & -0.84 & 0.06 & 0.18 & 38 & $-9.7^{*}$ \\
\hline Sweden & -0.26 & -0.26 & -0.43 & 0.02 & 0.11 & 42 & $-15.4^{*}$ \\
\hline Switzerland & -0.14 & -0.15 & -0.24 & -0 & 0.07 & 16 & $-7.4^{*}$ \\
\hline Syrian Arab Republic & -0.28 & -0.30 & -0.31 & -0.23 & 0.04 & 3 & $-11.5^{*}$ \\
\hline Tajikistan & -0.54 & -0.57 & -0.83 & -0.28 & 0.19 & 14 & $-10.6^{*}$ \\
\hline Tanzania & -0.53 & -0.56 & -0.77 & -0.20 & 0.16 & 37 & $-20.3^{*}$ \\
\hline Thailand & -0.42 & -0.40 & -0.71 & -0.19 & 0.17 & 35 & $-14.2^{*}$ \\
\hline Togo & -0.26 & -0.24 & -0.53 & 0.01 & 0.12 & 42 & $-13.9^{*}$ \\
\hline Tonga & -0.47 & -0.45 & -0.72 & -0.27 & 0.12 & 23 & $-19.6^{*}$ \\
\hline Trinidad and Tobago & -0.01 & -0 & -0.45 & 0.41 & 0.20 & 42 & $-0.2^{*}$ \\
\hline Tunisia & -0.50 & -0.50 & -0.77 & -0.20 & 0.12 & 42 & $-28.1^{*}$ \\
\hline Turkey & -0.51 & -0.53 & -0.85 & -0.12 & 0.18 & 42 & $-18.6^{*}$ \\
\hline Uganda & -0.35 & -0.34 & -0.80 & 0.18 & 0.30 & 32 & $-6.7^{*}$ \\
\hline Ukraine & -0.40 & -0.43 & -0.72 & -0.05 & 0.22 & 16 & $-7.3^{*}$ \\
\hline United Kingdom & -0.28 & -0.26 & -0.67 & 0.05 & 0.18 & 42 & $-10.2^{*}$ \\
\hline Uruguay & -0.19 & -0.19 & -0.61 & 0.22 & 0.19 & 36 & $-5.8^{*}$ \\
\hline Vanuatu & -0.03 & -0.01 & -0.22 & 0.13 & 0.09 & 16 & $-1.2^{*}$ \\
\hline Venezuela & -0.15 & -0.14 & -0.64 & 0.24 & 0.25 & 42 & $-4.0^{*}$ \\
\hline Vietnam & -0.23 & -0.24 & -0.49 & 0.01 & 0.15 & 14 & $-5.7^{*}$ \\
\hline Yemen, Rep. & 0.02 & 0.06 & -0.35 & 0.24 & 0.18 & 15 & $0.5^{*}$ \\
\hline Zambia & -0.38 & -0.25 & -0.82 & 0.07 & 0.27 & 42 & $-9.1^{*}$ \\
\hline
\end{tabular}


Table A1 - continued from previous page

\begin{tabular}{cccccccr} 
Country & Mean & Median & Min & Max & SD & N & t-stat \\
\hline Zimbabwe & -0.61 & -0.69 & -0.83 & -0.09 & 0.22 & 24 & $-13.6^{*}$ \\
\hline \hline
\end{tabular}

Notes: $H_{0}:$ Mean $=0, H_{1}:$ Mean $>0$. A “*" indicates that we cannot reject $H_{0}$ at the $5 \%$ level. 